\title{
ROCK STRENGTH ANISOTROPY IN HIGH STRESS CONDITIONS: A CASE STUDY FOR APPLICATION TO SHAFT STABILITY ASSESSMENTS
}

\author{
JULIAN MATTHEW WATSON \\ Geotechnical Engineering \& Hydrogeology, KGHM International, Ltd., \\ Suite 202 - 8105 Birch Bay Square St, Blaine, WA, USA 98230, e-mail: Julian.Watson@kghm.com
}

ABOUZAR VAKILI

Mining One Pty, Ltd., Level 9, 50 Market Street, Melbourne, VIC, Australia 3000, e-mail: avakili@miningone.com.au

\author{
MATEUSZ JAKUBOWSKI
}

Business Development Department, KGHM Polska Miedź S.A., ul. Marii Sklodowskiej-Curie 48, 59-301 Lubin, Poland, e-mail: m.jakubowski@kghm.pl

\begin{abstract}
Although rock strength anisotropy is a well-known phenomenon in rock mechanics, its impact on geotechnical design is often ignored or underestimated. This paper explores the concept of anisotropy in a high stress environment using an improved unified constitutive model (IUCM), which can account for more complex failure mechanisms. The IUCM is used to better understand the typical responses of anisotropic rocks to underground mining. This study applies the IUCM to a proposed rock shaft located in high stress/anisotropic conditions. Results suggest that the effect of rock strength anisotropy must be taken into consideration when assessing the rock mass response to mining in high stress and anisotropic rock conditions.
\end{abstract}

Key words: anisotropy, high stress, numerical modeling, constitutive model

\section{INTRODUCTION}

The significance of rock strength anisotropy (anisotropy) in geotechnical design is often ignored or underestimated when undertaking geotechnical analyses. This is partly due to most geotechnical design methods (whether empirical, numerical or analytical) being largely developed for isotropic rather than anisotropic rock mass conditions. Therefore, there is a tendency to ignore its impact, and to simplify the design process or apply conventional design methods. However, anisotropy can play a key role in the stability of underground excavations and subsequent geotechnical design. Experience suggests that, in many cases, anisotropy can have a far greater influence on failure mechanism than other factors such as the orientation of principal stress vectors. Furthermore, anisotropy can significantly change the time dependent failure mechanism and progression of damage into the rock mass.
Recent literature, such as that of Sandy et al. [20], Vakili, et al. [25], Hadjigeorgiou et al. [8], and Vakili et al. [24] outlines the typical response of anisotropic rock masses to increasing stress levels and shows examples of geotechnical design in these conditions. This paper applies the recently developed IUCM and illustrates how this methodology can more reliably explain the rock mass response to mining under high stress and anisotropic conditions than do commonly used geotechnical design methods.

\section{CASE STUDY AND APPROACH}

The case study for this paper focuses on KGHM International, Ltd.'s Victoria Project, located approximately $50 \mathrm{~km}$ west of Sudbury, in the Sudbury Basin, Ontario, Canada. Access to the base metals 
(Cu-Ni-TPM) orebody will be via a vertical shaft located in the hangingwall lithological units.

For this study, a section of metacrystal gabbro (MXGB) located between $970 \mathrm{~m}$ and $1000 \mathrm{~m}$ below surface was modelled using 3D numerical software and the IUCM. Shaft sinking parameters (including sequence) and installation of a cementitious liner was explicitly modelled.

\section{INPUT DATA}

The input data used in this case study are based on logging and rock property testing information provided by the Victoria Project (see Tables 1 and 2) and associated with the proposed production shaft pilot bore hole (FNX1204). The geological strength index
(GSI) was calculated using equations suggested by Hoek et al. [10] and Jr, Ja and RQD data from drillhole logs (see equation (1)).

$$
\mathrm{GSI}=\frac{52 \mathrm{Jr} / \mathrm{Ja}}{(1+\mathrm{Jr} / \mathrm{Ja})}+\mathrm{RQD} / 2
$$

\section{FAR FIELD STRESS}

While in-situ mini-frac stress estimates of far-field stress conditions were completed for the Victoria Project, the reliability of the results was unclear. Therefore, the far-field stress boundary conditions for this study are based on published data by Trifu and Suorineni [21] (see Table 3).

Table 1. Summary of input data used in this case study

\begin{tabular}{|c|c|c|}
\hline Input & Value & Comments \\
\hline $\begin{array}{l}\text { Unconfined } \\
\text { compressive } \\
\text { strength (UCS) }\end{array}$ & $150 \mathrm{MPa}$ & $\begin{array}{l}4 \text { tests were completed. } 2 \text { failed on foliation. The lower value of } \\
\text { tests which failed through intact rock matrix was chosen }\end{array}$ \\
\hline Intact modulus $(\varepsilon i)$ & $53000 \mathrm{MPa}$ & $\begin{array}{l}\text { The modulus associated with samples failed on intact rock matrix } \\
\text { was chosen }\end{array}$ \\
\hline $\begin{array}{l}\text { Hoek-Brown } \\
\text { constant } m i\end{array}$ & 8 & $\begin{array}{l}\text { No triaxial tests were available. Published values suggest } m i \\
\text { of } 27 \pm 3 \text { for Gabbro but as demonstrated by Brown [4], a } m i \\
\text { value equal to UCS/UTS gives a closer estimate to real } m i \text { than } \\
\text { published data }\end{array}$ \\
\hline $\begin{array}{l}\text { Anisotropy } \\
\text { factor }\end{array}$ & 2 & $\begin{array}{l}\text { This is the ratio between rock matrix UCS and lowest UCS when } \\
\text { beta angle is between } 30^{\circ}-45^{\circ}(151 \mathrm{MPa} / 74 \mathrm{MPa})\end{array}$ \\
\hline $\begin{array}{l}\text { Orientation } \\
\text { of foliation } \\
\text { plane }\end{array}$ & $\begin{array}{l}\quad \text { Dip }=63^{\circ} \\
\text { Azimuth }=283^{\circ}\end{array}$ & Obtained from structural interpretations \\
\hline GSI & 70 & $\begin{array}{l}\text { GSI was calculated using equations suggested by Hoek et al. [10] } \\
\text { and Jr, Ja and RQD data from drillhole logs }\end{array}$ \\
\hline
\end{tabular}

Table 2. UCS values used in this case study

\begin{tabular}{|c|c|c|c|c|c|c|c|c|}
\hline \multirow{2}{*}{$\begin{array}{c}\text { Results } \\
\text { sample ID }\end{array}$} & $\begin{array}{c}\text { Sample depth } \\
(\mathrm{m})\end{array}$ & from & Rock & $\begin{array}{c}\text { Density } \\
\text { type }\end{array}$ & $\begin{array}{c}\text { UCS } \\
\left(\mathrm{g} / \mathrm{cm}^{3}\right)\end{array}$ & $\begin{array}{c}\text { Young's } \\
\text { for) } \\
\text { modulus } \\
(\mathrm{GPa})\end{array}$ & $\begin{array}{c}\text { Poisson's } \\
\text { ratio }\end{array}$ & $\begin{array}{c}\text { Brazilian } \\
\text { tensile } \\
\text { strength } \\
\text { (MPa and } \\
\text { range })\end{array}$ \\
\hline H817457 & 495.7 & 496.0 & MXGB & 3.07 & 191.6 & 56.5 & 0.10 & - \\
\hline H817458 & 812.0 & 812.3 & MXGB & 3.04 & 151 & 53.1 & 0.10 & $18.5(14.7-23)$ \\
\hline H817459 & 802.5 & 720.5 & MXGB & 2.72 & $87.1(\mathrm{pf})$ & 44.7 & 0.10 & - \\
\hline H817460 & 653.9 & 654.3 & MXGB & 3.01 & $74.2(\mathrm{f})$ & 51.1 & 0.11 & - \\
\hline
\end{tabular}

Note: $\mathrm{f}=$ complete failure of laboratory test sample; $\mathrm{pf}=$ partial failure of laboratory test sample 
Table 3. Far field stress regime assumed for this case study

\begin{tabular}{|c|c|}
\hline $\begin{array}{c}\text { Principal stress } \\
(\mathrm{MPa})\end{array}$ & $\begin{array}{c}\text { Magnitudes } \\
\text { (after Trifu and Suorineni [21]) }\end{array}$ \\
\hline$\sigma 1$ & $10.9+0.0407 \mathrm{Z}$ \\
\hline$\sigma 2$ & $8.7+0.0326 \mathrm{Z}$ \\
\hline$\sigma 3$ & $0.029 \mathrm{Z}$ \\
\hline
\end{tabular}

Note: $Z=$ depth below surface $(m)$

\section{THE IMPROVED UNIFIED CONSTITUTIVE MODEL (IUCM)}

The IUCM was developed by Vakili et al. [23] as a result of previous work on rock damage processes and review of previous literature. After being tested on a number of well-documented case histories, it was shown that this unified model could forecast the extent and severity of damage more accurately than other conventional methods. The key concepts and components of the IUCM are presented in Fig. 1 and Table 4, respectively.

This constitutive model is implemented in the explicit finite difference code FLAC3D (ITASCA Consulting Group [13]) and therefore uses a timestepping solution for calculations. As a result, progressive and time-dependent failure can be replicated in this model through updating the material properties as a function of new confinement and strain levels. The key input parameters used in the IUCM for anisotropic rock are:

- Elastic modulus of intact rock,

- UCS of intact rock $\left(\sigma c_{\max }\right)$,

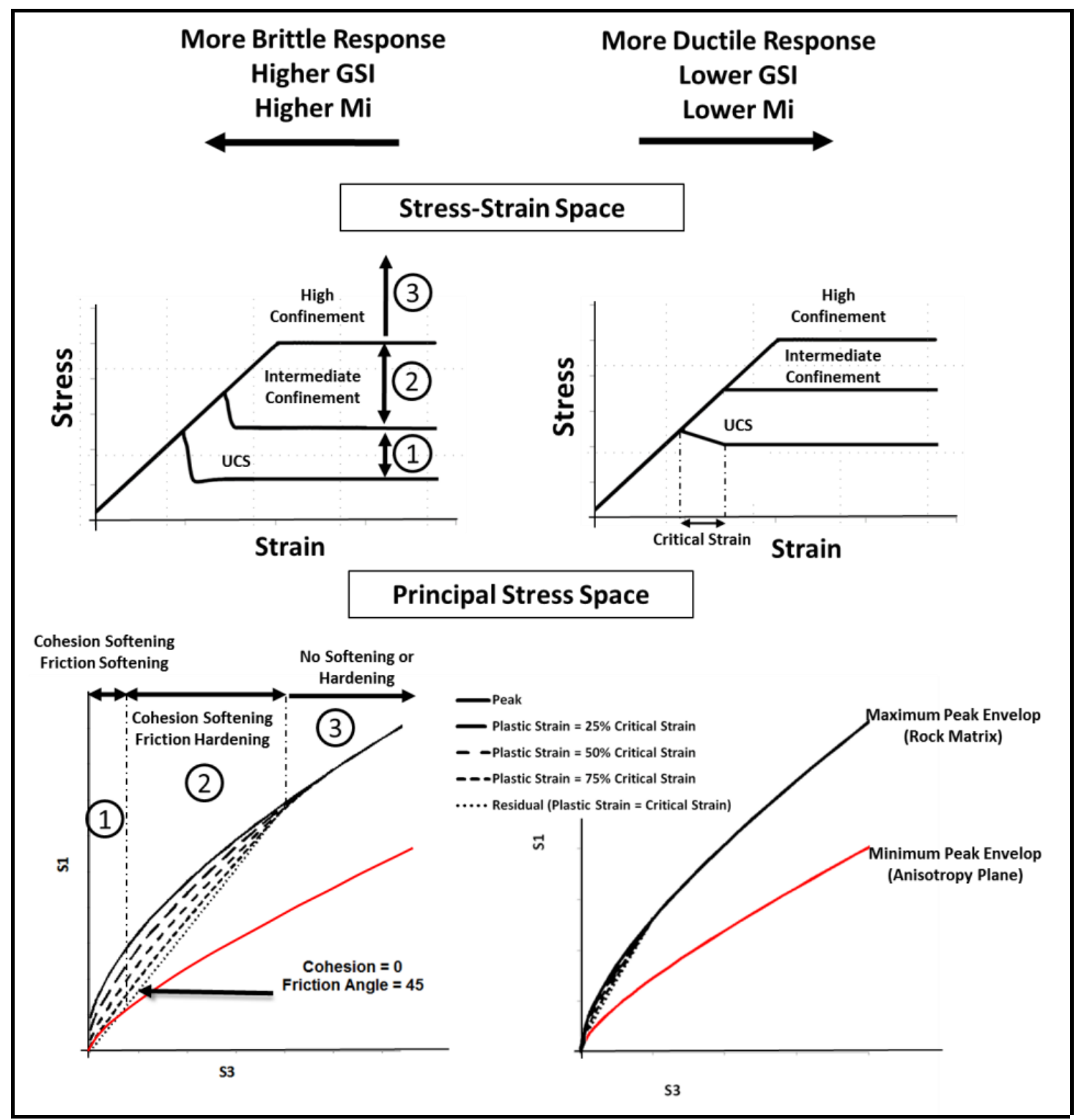

Fig. 1. A conceptual representation of different components of the IUCM (after Vakili et al. [23]) 
Table 4. Key components of the IUCM (after Vakili et. al. [23])

\begin{tabular}{|c|c|c|}
\hline Component & Derivation & Comment \\
\hline $\begin{array}{l}\text { Peak failure } \\
\text { envelope of } \\
\text { the rock ma- } \\
\text { trix }\end{array}$ & $\begin{array}{l}\text { Hoek-Brown (2002) failure criterion used to } \\
\text { determine the instantaneous Mohr-Coulomb } \\
\text { parameters ( } c \text { and Phi) at each level of } \\
\text { confining stress. }\end{array}$ & $\begin{array}{l}\text { These instantaneous parameters are updated in real time as the } \\
\text { model runs and as new phases of confinement are formed due to } \\
\text { nearby damage or geometrical changes. }\end{array}$ \\
\hline $\begin{array}{l}\text { Residual state } \\
\text { of the rock } \\
\text { matrix }\end{array}$ & $\begin{array}{l}\text { A linear Mohr-Coulomb envelope is as- } \\
\text { signed. Properties of completely broken and } \\
\text { crushed rock are applied for the residual } \\
\text { state of the material using a cohesion and } \\
\text { tensile strength of zero and a friction angle } \\
\text { of } 45^{\circ} \text { (as recommended by Lorig and } \\
\text { Varona [16]). }\end{array}$ & $\begin{array}{l}\text { At low confinement levels, the linear nature of the residual enve- } \\
\text { lope replicates cohesion and friction softening. At high confinement } \\
\text { levels, it replicates cohesion softening and friction hardening. This } \\
\text { feature of the model allows progressive failure to occur near the } \\
\text { boundary of the excavation. At the same time, it limits the propa- } \\
\text { gation of yield or plasticity zones away from the excavation } \\
\text { boundaries (as observed in the field). }\end{array}$ \\
\hline Critical strain & $\begin{array}{l}\text { Based on equations suggested by Lorig and } \\
\text { Varona }[16] .\end{array}$ & $\begin{array}{l}\text { Critical strain values are determined based on model zone size and } \\
\text { the GSI values. This critical strain can also be adjusted when syn- } \\
\text { thetic rock mass (SRM) testing results are available. }\end{array}$ \\
\hline Dilation angle & $\begin{array}{l}\text { Determined through a ratio (dilation angle/ } \\
\text { friction angle) that is estimated as a function } \\
\text { of the GSI of the rock mass and multiplied } \\
\text { by instantaneous friction angles in the model. }\end{array}$ & $\begin{array}{l}\text { The non-linear nature of the peak failure envelope and the associ- } \\
\text { ated instantaneous friction angles in this model result in higher } \\
\text { dilation angles at lower confinement, and lower dilation angles at } \\
\text { higher confinement. This behaviour is similar to that observed in } \\
\text { laboratory rock testing results. The dilation angle is also mobilised } \\
\text { and softens with increasing plastic shear strain in the model and } \\
\text { drops to its residual value ( } 30 \text { per cent of the instantaneous friction } \\
\text { angle) when the critical strain limit is exceeded. The basis for the } \\
\text { dilation angle calculations is largely derived from Zhao and Cai } \\
\text { [26] and Lorig and Varona[16]. }\end{array}$ \\
\hline $\begin{array}{l}\text { Modulus } \\
\text { Softening }\end{array}$ & $\begin{array}{l}\text { Empirical relationship developed by Reyes- } \\
\text { Montes et al. [19] between modulus drop } \\
\text { and the level of porosity in a rock mass. }\end{array}$ & $\begin{array}{l}\text { IUCM uses this relationship to update the elastic modulus values } \\
\text { according to new porosity levels. The porosity is calculated using } \\
\text { the model volumetric strain outputs. The density in the model is } \\
\text { also updated as a result of new porosity levels. }\end{array}$ \\
\hline $\begin{array}{l}\text { Strength ani- } \\
\text { sotropy }\end{array}$ & $\begin{array}{l}\text { For anisotropic rocks, the model uses two } \\
\text { non-linear Hoek-Brown failure envelopes. } \\
\text { One envelope defines the maximum strength } \\
\text { and is related to the rock matrix strength. The } \\
\text { other defines the minimum strength associ- } \\
\text { ated with the anisotropy plane. }\end{array}$ & $\begin{array}{l}\text { Explicitly included through a ubiquitous joint model, which ac- } \\
\text { counts for both rock matrix strength and the lower strength associ- } \\
\text { ated with the existence of an anisotropy plane. }\end{array}$ \\
\hline
\end{tabular}

- anisotropy factor $\left(\sigma c_{\max } / \sigma c_{\min }\right)$,

- $m i_{\min }$

- $m i_{\max }$

- GSI.

All of the above parameters can be determined from laboratory testing and core logging or structural mapping.

\section{INTERPRETATION OF RESULTS}

In order to interpret results, a volumetric strain criterion was used to investigate the potential depth of failure. Volumetric strain is the unit change in volume due to a deformation $\left(\Delta V / V_{0}\right)$ and is calculated by the sum of the major, minor, and intermediate principal strain components $(\varepsilon 1+\varepsilon 2+\varepsilon 3)$. A negative volumetric strain implies a contraction of the rock mass and a positive value indicates dilation. Contraction occurs at high confinement levels, while dilation happens in lower confinement zones such as near the boundary of an excavation. The failure mechanism leading to breakout is most often controlled by a dilatational volumetric strain induced near the boundary of the excavation.

Figure 2 is a representation of various volumetric strains with respect to degree of disintegration as simulated in a fully discontinuum model through modeling of uniaxial loading of a rock sample. Experience in numerical back analysis at several mining operations showed that a model volumetric strain of between $1 \%$ to $3 \%$ often generates similar or close to overbreak/breakout volumes to those obtained from actual underground excavations. Examples of some of these back analysis studies completed on various underground excavations are shown in Fig. 3. 


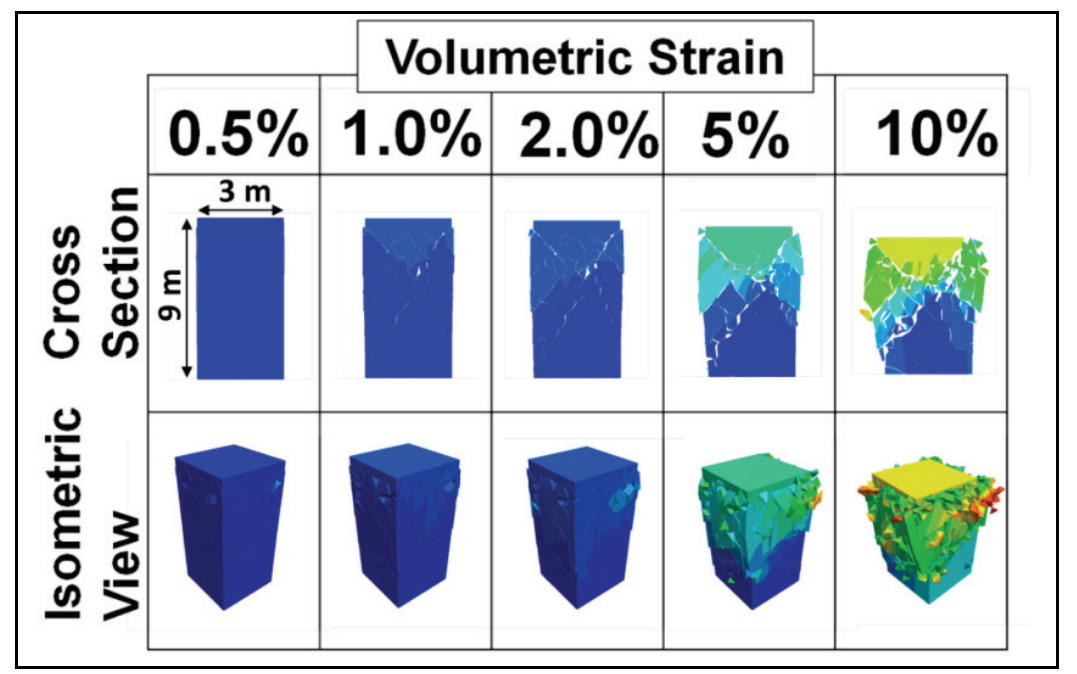

Fig. 2. Visual representation of degree of rock disintegration at various levels of volumetric strain (after Vakili et al. [23])

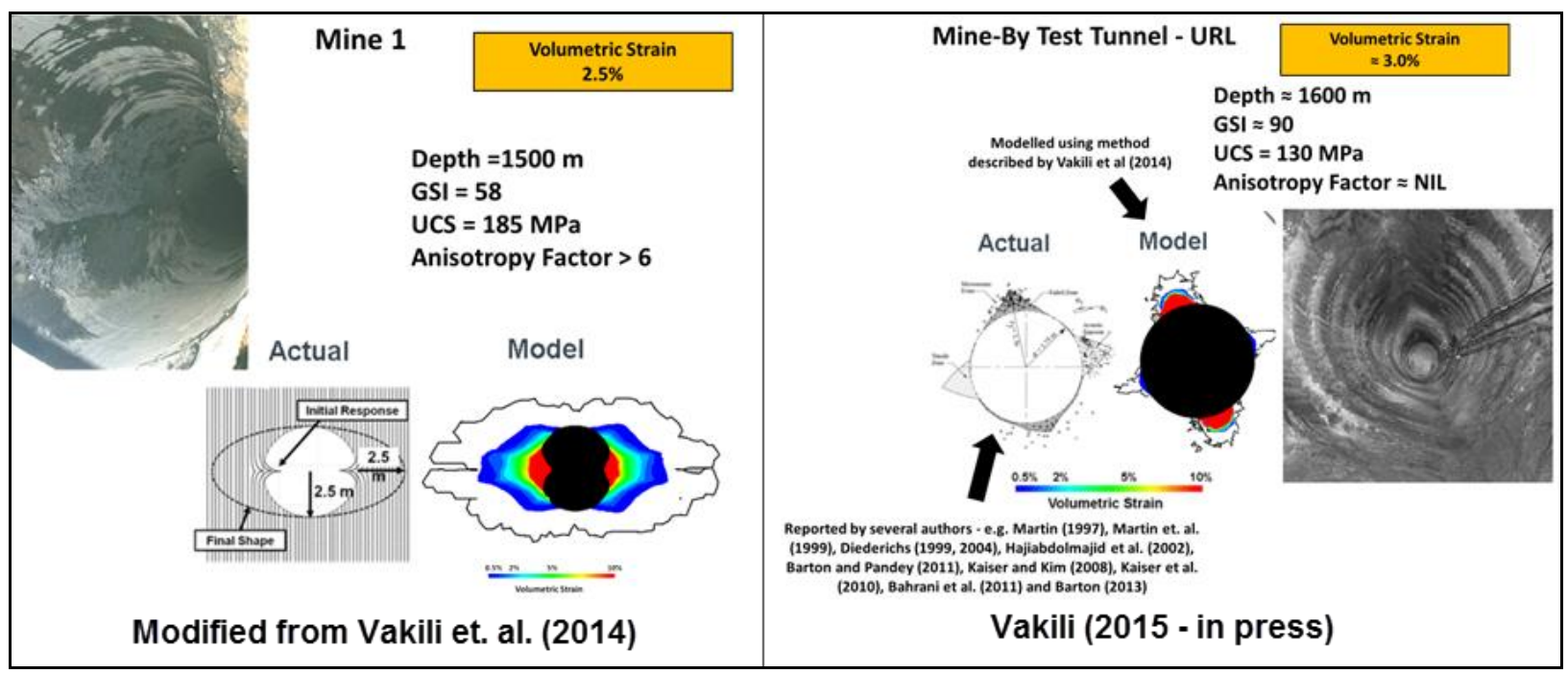

Fig. 3. Examples of some of back analysis completed during development of the ICUM, preformed on various underground excavations

\section{STABILITY ASSESSMENT OF SHAFT LINER}

For stability assessment of the cementitious liner, liner displacement, and moment-thrust capacity diagrams (and associated Factor of Safety) were used.

Definition and analysis procedures of momentthrust capacity diagrams were presented by CarranzaTorres and Diederichs [5]. Hoek et al. [11] also applied the technique for tunnel design. This approach provides an indicative measure of liner stability.

The graphical representation of induced axial thrust and bending moment on a liner plotted together with the corresponding "envelope of failure" (defined, for exam- ple, by the maximum values of axial thrust and bending moment that the support is allowed to withstand) is referred to as the thrust-bending moment interaction diagram. Similar plots can be established to investigate the Thrust-Shear diagrams and the potential for shear failure. However due to time constraints the Thrust-Shear diagrams were not included in this study.

These diagrams are useful tools for the design of cementitious liners, since they allow easy quantification of the performance of a support. For the particular values of compressive and tensile strength of liner the thrust-moment interaction diagram can be used to obtain the factor of safety (FS) for failure of the arch in tension or compression - for example if points corresponding to the loading state in the arch are 


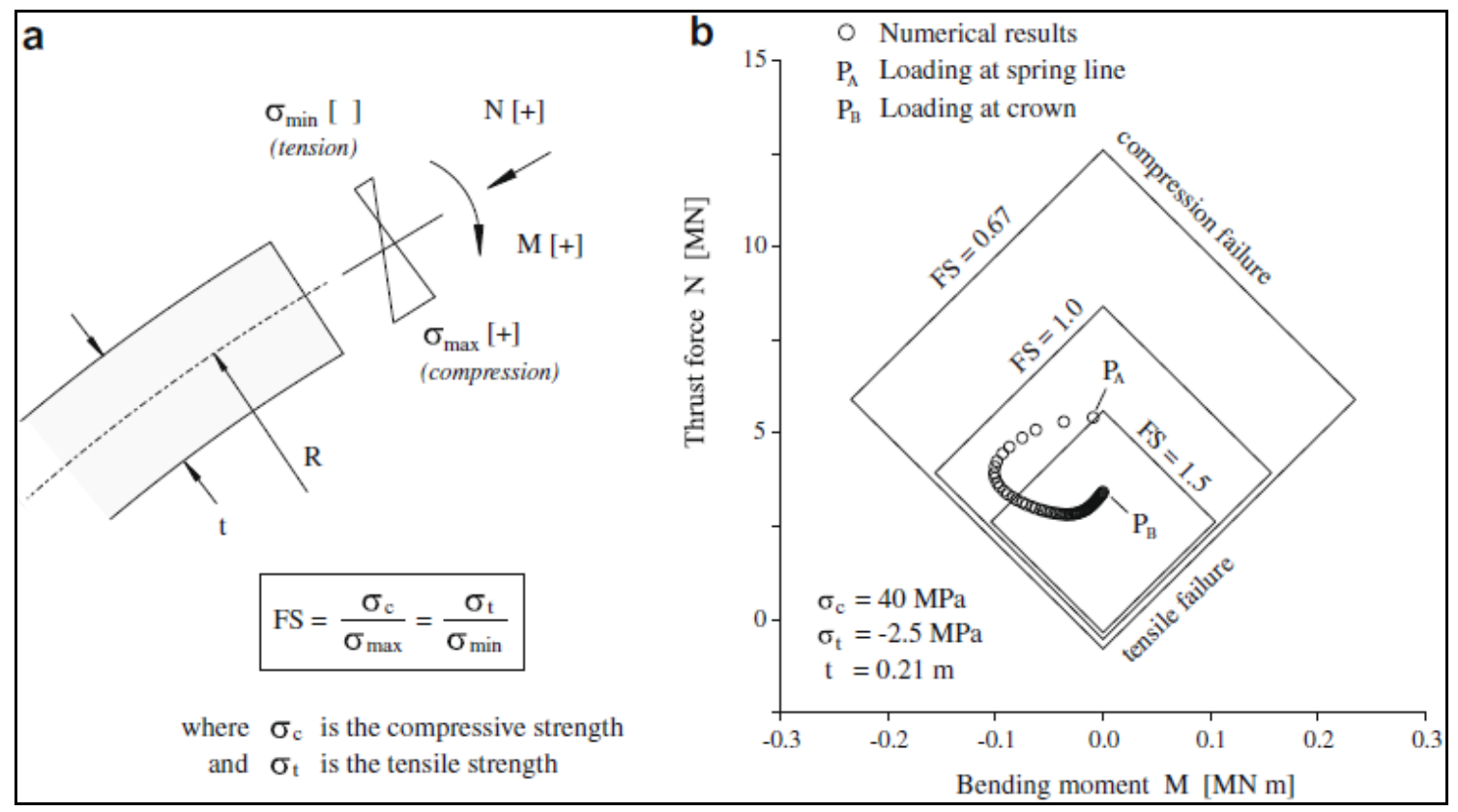

Fig. 4. (a) FS defined in terms of maximum and minimum axial stresses on a section of circular arch; (b) graphical representation of results from the ground support interaction analysis, in a thrust-bending moment interaction diagram (after Carranza-Torres and Diederichs [5])

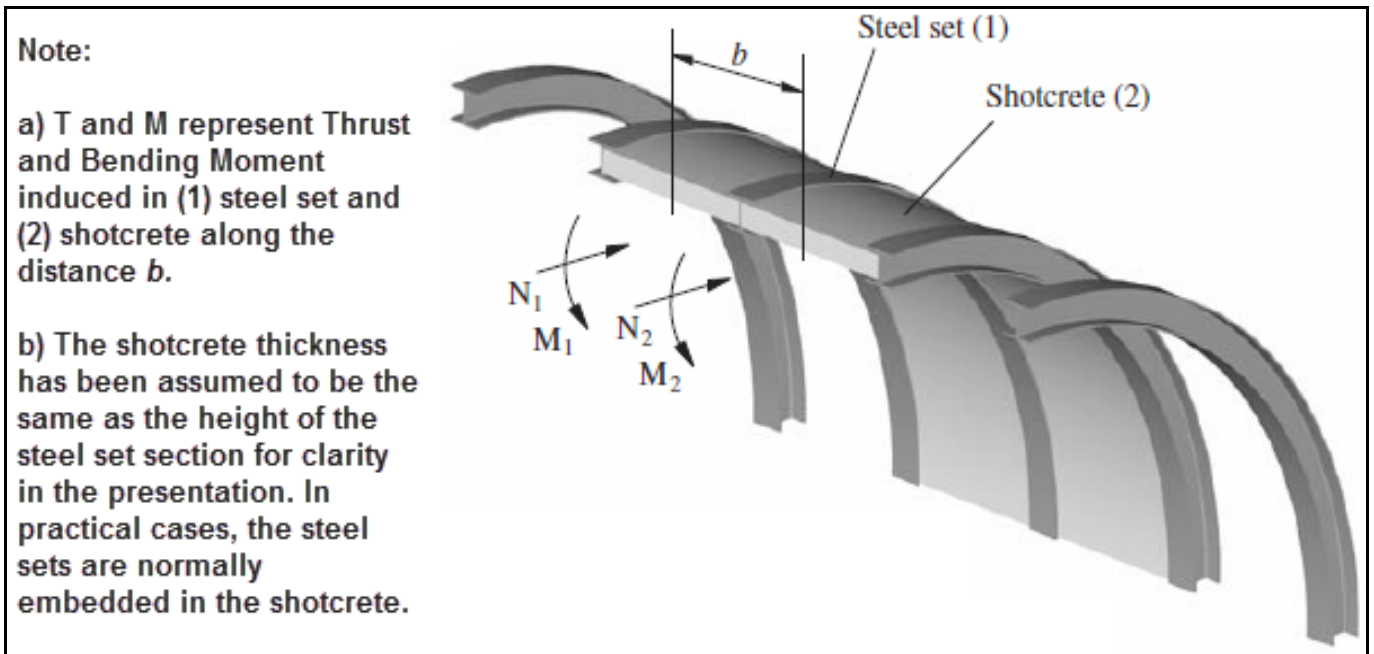

Fig. 5. Schematic representation of thrust and bending moment distribution in a liner consisting of shotcrete and steel sets (after Carranza-Torres and Diederichs [5])

bounded by the isoline $\mathrm{FS}=1.0$, it means that the support is able to withstand the thrust and bending moment induced by excavation of the tunnel, without exceeding the elastic limit of the material.

\section{MODEL CALIBRATION}

The model was calibrated using borehole breakout information which was observed in the acoustic televiewer data from the proposed production shaft pilot hole (FNX1204). The identified breakout (Fig. 5) was recorded in the same lithology as that being modelled for the shaft (MXGB). Given the localised nature of the breakout (only occurring at a short interval), no adjustments were applied to the adopted rock properties. Instead, a number of sensitivity models were completed to investigate the possible failure mechanism that was in place when the breakout was formed (Fig. 6). Other sections of the pilot hole showed no signs of breakout. Therefore, it is not possible to rule out the derived 


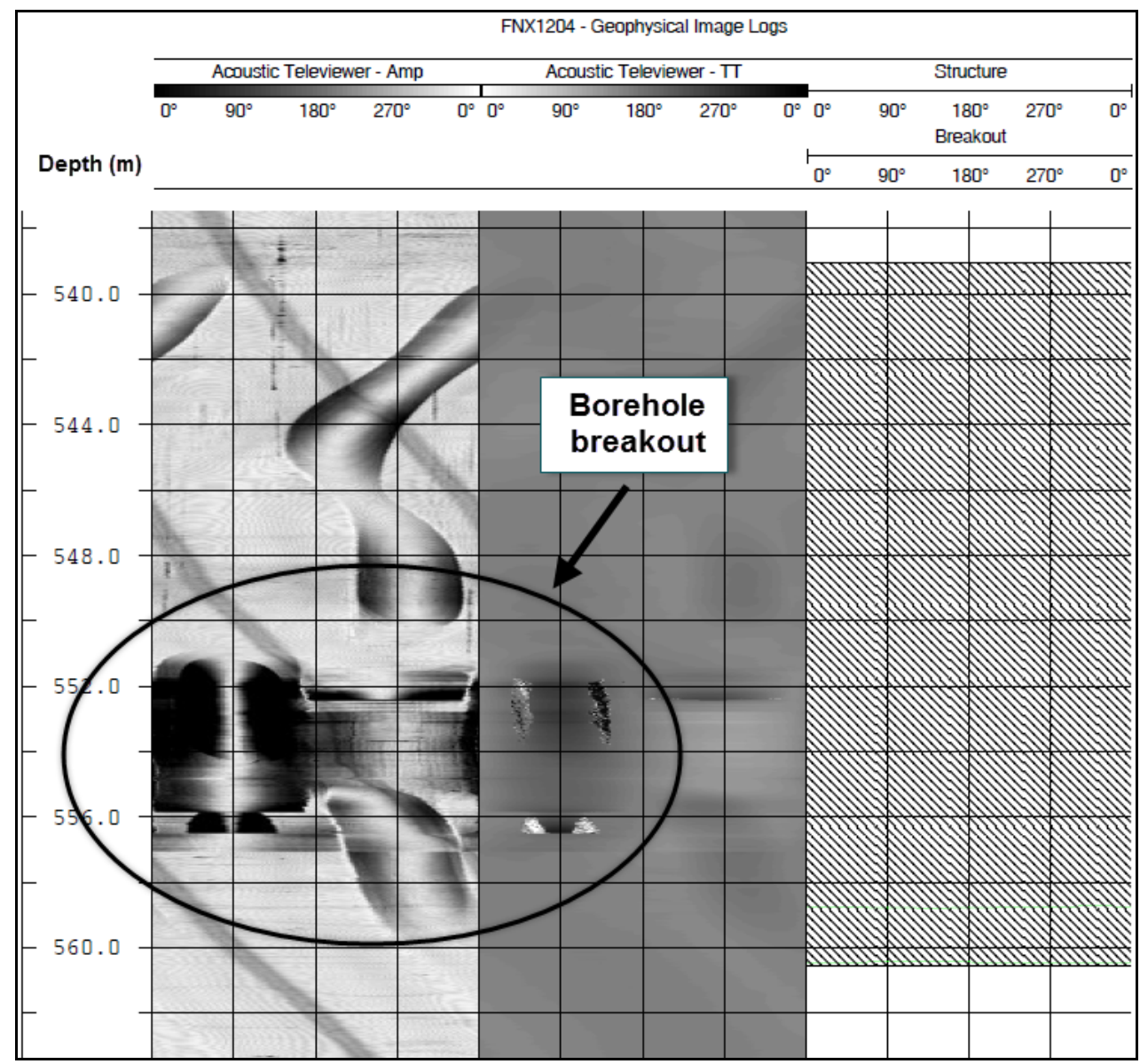

Fig. 6. Borehole break out noted in shaft pilot hole (FNX1204) between $\sim 551 \mathrm{~m}$ and $557 \mathrm{~m}$ below surface (down hole)

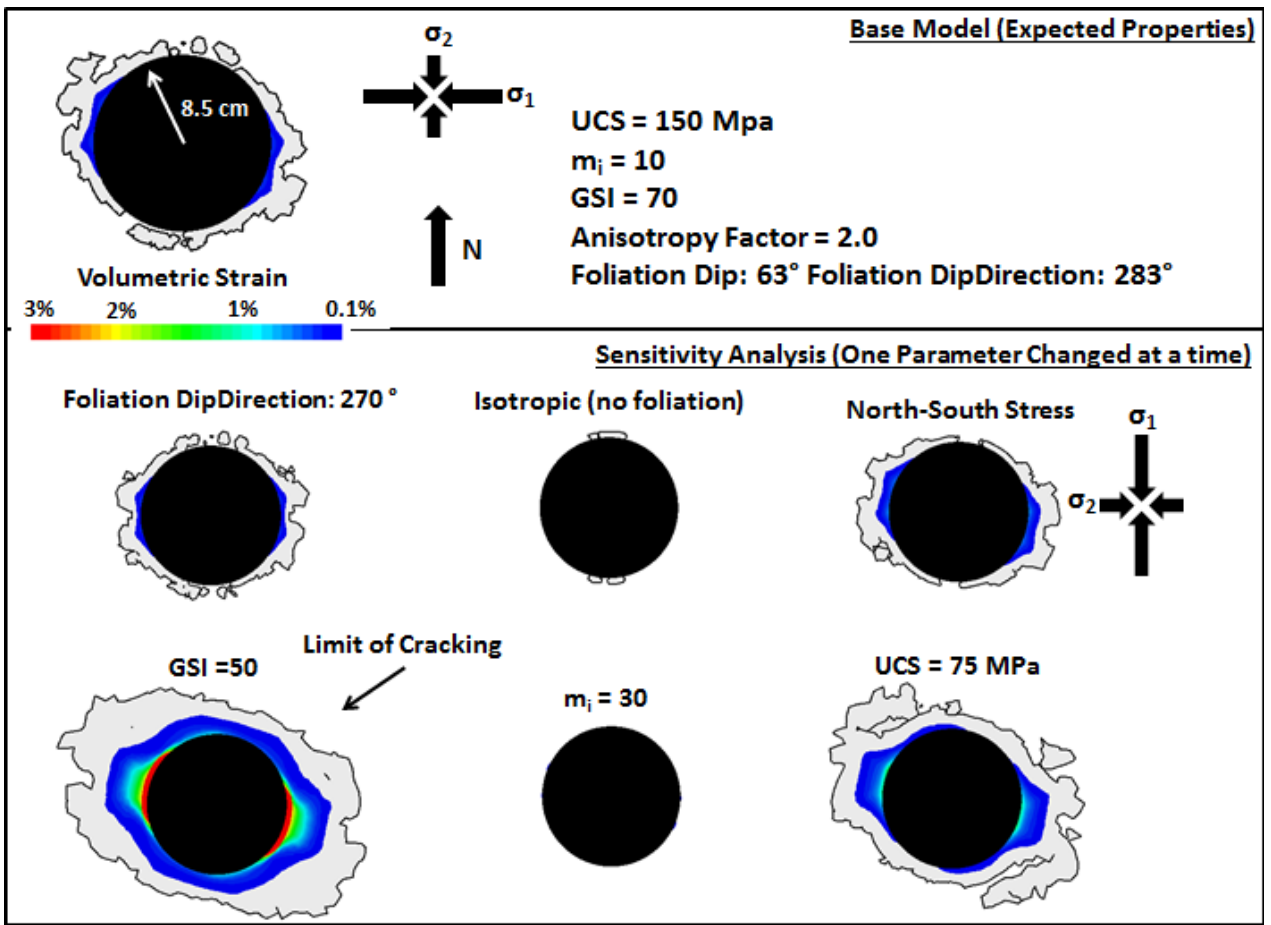

Fig. 7. Sensitivity models were completed during calibration investigating the possible failure mechanism that was in place when the breakout was formed. It was found that the model was most sensitive to modification of GSI and UCS values and anisotropy (i.e., orientation and intensity of the foliation plane) 


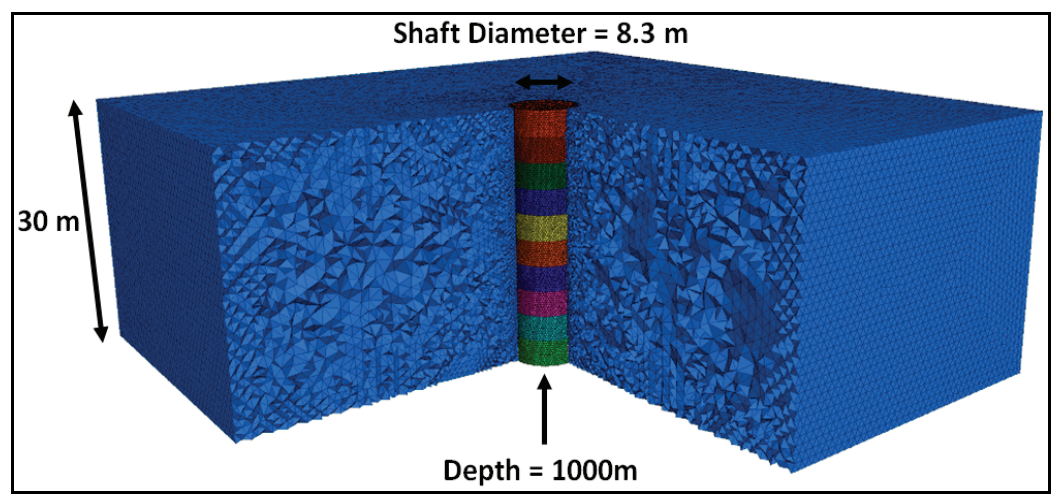

Fig. 8. Model and shaft geometry applied in 3D numerical model

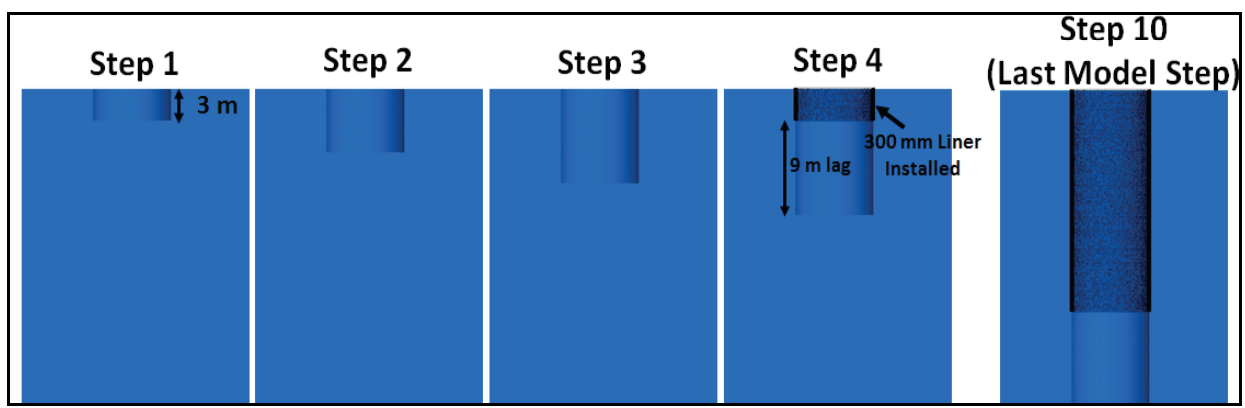

Fig. 9. Mining geometry and sequence applied in 3D numerical model

expected properties. As can be seen in Figure 6, while the model is influenced by changes to GSI and UCS values, the greatest effect is associated with anisotropy (i.e., orientation and intensity of the foliation plane).

\section{FORWARD-ANALYSIS}

The forward analysis explicitly included sinking of the shaft (i.e., mining steps) and installation of a cementitious liner. The associated assumptions are outlined in Figs. 7 and 8, respectively.

Table 5. Assumed inputs for of shaft liner stability assessment

\begin{tabular}{|c|c|c|}
\hline \multicolumn{2}{|c|}{ Component } & Assumed value \\
\hline \multicolumn{2}{|c|}{ Shaft diameter (m) } & 8.3 \\
\hline \multicolumn{2}{|c|}{ Shaft advance ${ }^{(1)}(\mathrm{m})$} & 3 \\
\hline \multicolumn{2}{|c|}{ Lag distance ${ }^{(2)}(\mathrm{m})$} & 9 \\
\hline \multicolumn{2}{|c|}{ Liner thickness $(\mathrm{mm})$} & 300 \\
\hline \multicolumn{2}{|c|}{ Shaft diameter (final) (m) } & 7.7 \\
\hline \multirow{2}{*}{ Liner strength } & $\mathrm{UCS}^{(3)}(\mathrm{MPa})$ & 35 \\
\hline & $\mathrm{UTS}^{(4)}(\mathrm{MPa})$ & 3 \\
\hline
\end{tabular}

\footnotetext{
(1) Vertical shaft sinking depth increment.

(2) Minimum distance between shaft bottom and installation of shaft liner.

(3) Unconfined compressive strength.

(4) Unconfined tensile strength.
}

\section{RESULTS}

The 3D numerical modeling results for depth of failure are presented in Fig. 9. The expected depth of failure of the shaft wall is suggested to be less than $0.5 \mathrm{~m}$ (based on 3\% volumetric strain) in the MXGB lithology, at depths of around $1000 \mathrm{~m}$ below surface. The maximum depth of failure under the same conditions is anticipated to be $\sim 1 \mathrm{~m}$ (based on $0.5 \%$ volumetric strain).

Based on the shaft liner stability assessment approach outlined by Carranza-Torres and Diederichs [5], the cementitious liner is assessed to be stable at a depth of approximately $1000 \mathrm{~m}$ below surface, with a FS of between 1.5 to 2 , when the lag distance is greater than $9 \mathrm{~m}$ (see Fig. 10).

\section{CONCLUSIONS}

This case study has enabled application of the IUCM approach to assess the stability of a proposed rock shaft. The results suggest that while the influence of GSI and UCS values are significant, anisotropy has the greatest control on rock mass response to mining (i.e., depth of failure) under high stress conditions. 


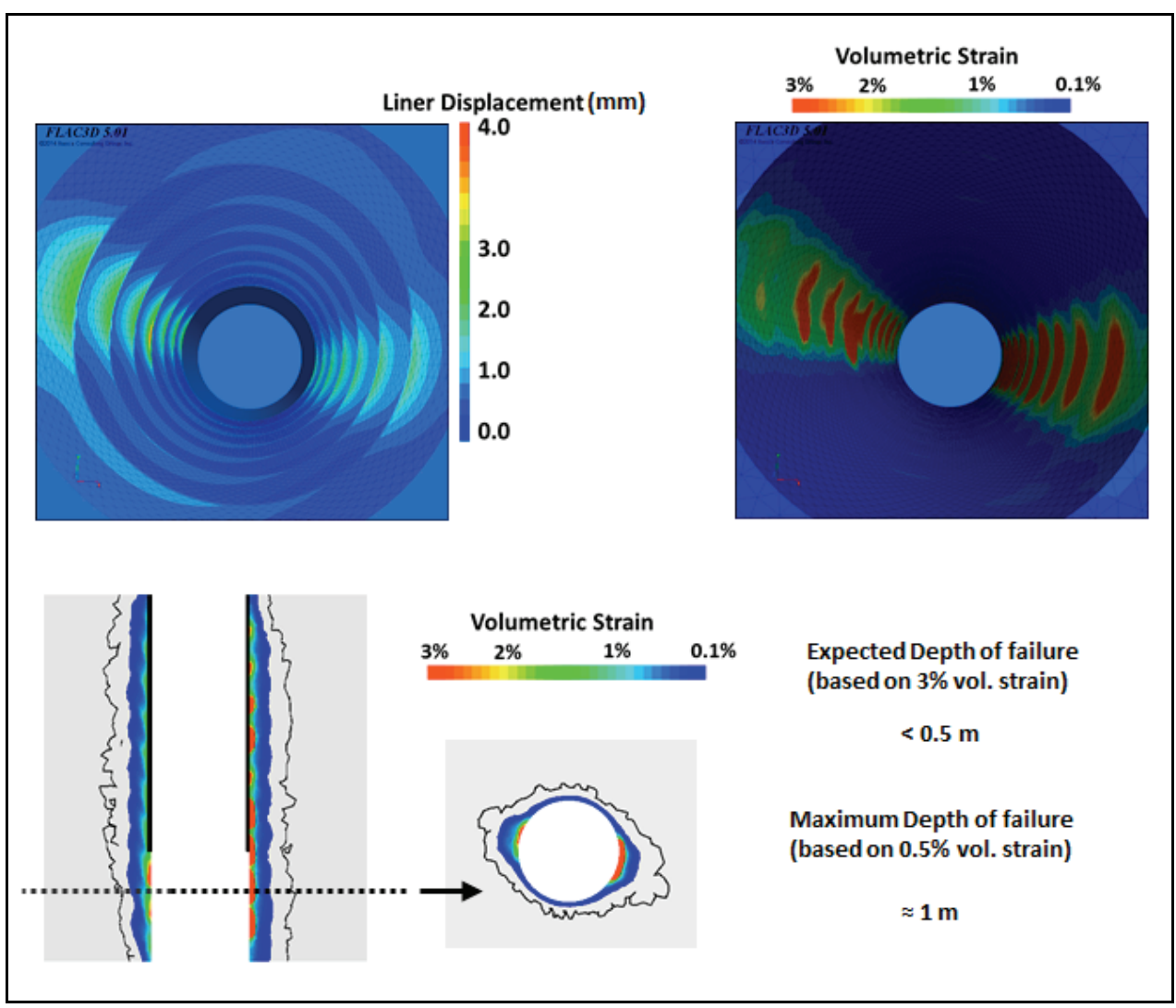

Fig. 10. 3D Numerical modelling results; expected and maximum depths of failure

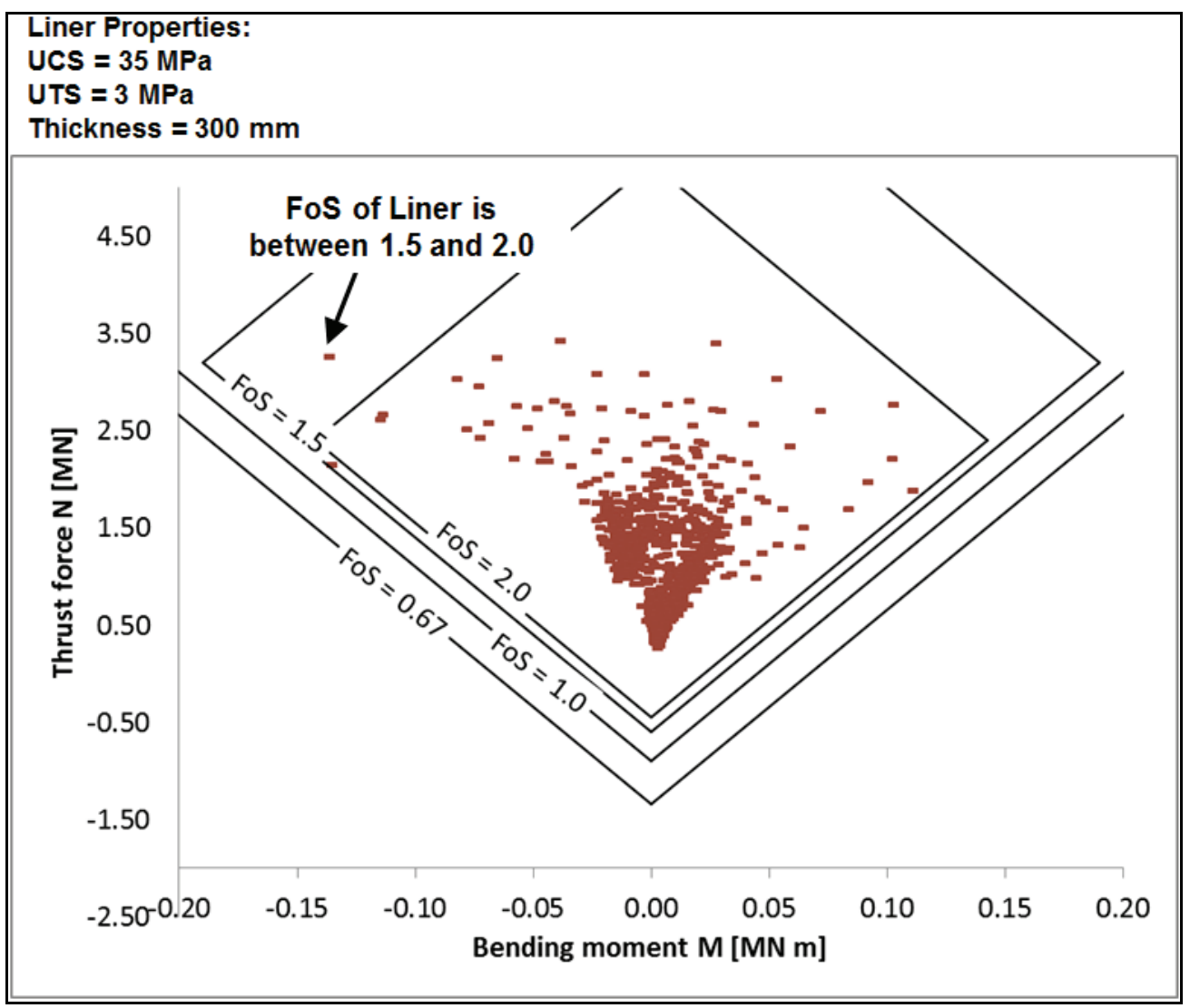

Fig. 11. Shaft stability assessment (after Carranza-Torres and Diederichs [5]) 
This is significant, given that anisotropy is often ignored in common geotechnical design methods, including calibration of and forecasting with numerical models.

\section{ACKNOWLEDGMENTS}

The authors would like to thank Professor Ted Brown and Mr. Mike Sandy for providing valuable feedback on this paper, along with KGHM International Ltd and KGHM Polska Miedź S.A. for allowing access to geotechnical data from the Victoria Project.

\section{REFERENCES}

[1] BARTON N., Shear strength criteria for rock, rock joints, rockfill and rock masses: Problems and some solutions, Journal of Rock Mechanics and Geotechnical Engineering, 2013, 5(4), 249-261, DOI: 10.1016/j.jrmge.2013.05.008.

[2] Barton N., PANDey S.K., Numerical modelling of two stoping methods in two Indian mines using degradation of $c$ and mobilization of $\varphi$ based on Q-parameters, International Journal of Rock Mechanics and Mining Sciences, 2011, 48(7), 1095-1112, DOI: 10.1016/j.ijrmms.2011.07.002.

[3] Bahrani N., VAlley B., Kaiser P.K., Discrete element modeling of drilling-induced core damage and its influence on laboratory properties of Lac De Bonnet granite, Proc. 45th US Rock Mechanics Conference, 26-29 June 2011, pp. 9, San Francisco, USA.

[4] Brown E.T., Estimating the mechanical properties of rock masses, Proceedings First Southern Hemisphere International Rock Mechanics Symposium, 16-19 September 2008, pp. 3-22, Perth, WA, Australia: The Australian Centre for Geomechanics.

[5] CARranza-Torres C., Diederichs M.S., Mechanical analysis of a circular liner with particular reference to composite supports - For example liners consisting of shotcrete and steel sets, Tunnelling and Underground Space Technology, 2009, 24(5), 506-532, DOI:10.1016/j.tust.2009.02.001.

[6] DIEDERICHS M.S., Instability of hard rockmasses: the role of tensile damage and relaxation, Unpublished doctoral dissertation, Department of Civil Engineering, University of Waterloo, Waterloo, Canada, 1999.

[7] Diederichs M.S., Kaiser P.K., Eberhardt E., Damage initiation and propagation in hard rock during tunnelling and the influence of near-face stress rotation, International Journal of Rock Mechanics and Mining Sciences, 2004, 41(5), 785-812, DOI: 10.1016/j.ijrmms.2004.02.003.

[8] Hadjigeorgiou J., Karampinos E., Turcote P., Mercier-LANGEVIN F., Assessment of the influence of drift orientation on observed levels of squeezing in hard rock mines, Seventh International Symposium on Ground Support in Mining and Underground Construction, 13-15 May 2013, pp. 109-117, Perth, WA, Australia, Australian Centre for Geomechanics.

[9] Hajiabdolmajid V., Kaiser P.K., Martin C.D., Modelling brittle failure of rock, International Journal of Rock Mechanics and Mining Sciences, 2002, 39(6), 731-741, DOI: 10.1016/S1365-1609(02)00051-5.

[10] Hoek E., Carter T.G., Diederichs M.S., Quantification of the geological strength index chart, 47th US Rock Mechan-
ics/Geomechanics Symposium, 23-26 June 2013, San Francisco, California, USA.

[11] Hoek E., CarranZa-Torres C., Diederichs M.S., Corkum B., Integration of geotechnical and structural design in tunnelling, Proceedings University of Minnesota 56th Annual Geotechnical Engineering Conference, 29 February 2008, pp. 1-53, Minneapolis, Minnesota, USA.

[12] Hoek E., Carranza-Torres C.T., Corkum B., HoekBrown failure criterion - 2002 edition, Proceedings of the Fifth North American Rock Mechanics Symposium (NARMS-TAC), 7-10 July 2002, pp. 267-273, Toronto, Ontario, Canada.

[13] ITASCA Consulting Group, Inc. (2012) FLAC3D - Fast Lagrangian Analysis of Continua in Three-Dimensions, Ver. 5.0. Minneapolis, Minnesota, USA.

[14] Kaiser P.K., Diederichs M.S., Martin C.D., Sharp J., STEINER W., Underground works in hard rock tunneling and mining. Keynote lecture, Geo-Eng 2000 International Conference on Geotechnical and Geological Engineering, 19-24 November 2000, pp. 841-926, Melbourne, Victoria, Australia.

[15] KAISER P.K., KIM B., Rock mechanics advances of underground construction and mining. Keynote lecture, Proceedings Korean Rock Mechanics, Symposium, October 2008, pp. 1-16, Seoul, South Korea: Korean Society for Rock Mechanics.

[16] LORIG L.J., VARONA P., Guidelines for numerical modelling of rock support for mines. Keynote lecture, Seventh International Symposium on Ground Support in Mining and Underground Construction, 13-15 May 2013, pp. 81-105, Perth, Western Australia, Australia: Australian Centre for Geomechanics.

[17] Martin C.D., Kaiser P.K., MCCreath D.R., Hoek-Brown parameters for predicting the depth of brittle failure around tunnels, Canadian Geotechnical Journal, 1999, 36(1), 136-151, DOI: $10.1139 / \mathrm{cgj}-36-1-136$.

[18] MarTin C.D., Seventeenth Canadian geotechnical colloquium: the effect of cohesion loss and stress path on brittle rock strength, Canadian Geotechnical Journal, 1997, 34(5), 698-725, DOI: 10.1139/cgj-34-5-698.

[19] Reyes-Montes M., Sainsbury B., Andrews J.R., Young R.P., Application of cave-scale rock degradation models in the imaging of the seismogenic zone, Proceedings Sixth International, Conference and Exhibition on Mass Mining, Massmin 2012, 10-14 June 2012, pp. 3-22, Sudbury, Ontario, Canada.

[20] Sandy M., Sharrock G., Albrecht J., Vakili A., Managing the transition from low-stress to high-stress conditions, Proceedings Second Australasian Ground Control in Mining Conference, 23-24 November 2010, pp. 247-254, Sydney, New South Wales, Australia, The Australasian Institute of Mining and Metallurgy.

[21] Trifu C., Suorineni F., Use of microseismic monitoring for rockburst management at Vale Inco mines, [in:] C. Tang (Ed.), Controlling Seismic Hazard and Sustainable Development of Deep Mines, Rinton Press, New York 2009, 1105-1114.

[22] VAKILI A., An improved unified constitutive model for rock material and a guideline for its application in numerical modelling, (Unpublished paper - currently under completion), 2015.

[23] Vakili A., Albrecht J., SAndy M., Rock strength anisotropy and its importance in underground geotechnical design, Proceedings AusRock 2014, Second Australasian 
Ground Control in Mining Conference, 5-6 November 2010, pp. 167-180, Sydney, New South Wales, Australia, The Australasian Institute of Mining and Metallurgy 2014.

[24] Vakili A., SAndy M., Mathews M., RodDA B., Ground support under highly stressed conditions, Proceedings Seventh International Symposium on Ground Support in Mining and Underground Construction, 13-15 May 2013, pp. 551564, Perth, Western Australia, Australia, Australian Centre for Geomechanics.
[25] Vakili A., SANDy M., Albrecht J., Interpretation of nonlinear numerical models in geomechanics - a case study in the application of numerical modelling for raise bored shaft design in a highly stressed and foliated rock mass, Proceedings sixth International Conference and Exhibition on Mass Mining, Massmin 2012, 10-14 June 2012, Sudbury, Ontario, Canada, The Canadian Institute of Mining, Metallurgy and Petroleum.

[26] ZHAO X.G., CAI M., A mobilized dilation angle model for rocks, International Journal of Rock Mechanics and Mining Sciences, 2010, 47(3), 368-384, DOI: 10.1016/j.jirmms.2009.12.007. 